\author{
Military Technical College \\ Kobry El-Kobbah, \\ Cairo, Egypt.
}

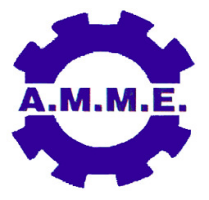

\title{
EGYPTIAN NUCLEAR ACTIVITIES AT RESEARCH REACTORS, LABORATORIES, AND URANIUM PRODUCTION (INDEPENDENT REVIEW)
}

\author{
$16^{\text {th }}$ International Conference \\ on Applied Mechanics and \\ Mechanical Engineering.
}

\author{
A. E. Mohamed*
}

\section{ABSTRACT}

In this seminar, I discuss and analysis the egyptian nuclear activities at research reactors, laboratories and uranium production as follows:

1- laboratories: External beta and gamma radiation is the main source of radioactivity in laboratories. Also, in some cases measurable radon-gas concentration are available as follows; "radon gas measurement- A portable radioactive gas monitor RGMI/L was used. It is sensitive to alpha particles emitted from radon gas. The unit is picocurie/ litre (pci/L) or microcurie per cubic meter $\left(\mathrm{mci} / \mathrm{m}^{3}\right)$. The maximum permissible concentration is 0.03 $\left(\mathrm{mci} / \mathrm{m}^{3}\right)$. I discuss the full activities of egyptian laboratories in anshass sites (two sites ) with the future activities.

2- Uranium production-The concentration of a semi-pilot plant for the extractions of uranium from phosphoric acid has been completed and was expected to be commissioned during 1999 and after. The design capacity of the plant is about $15 \mathrm{~m}^{3} /$ day (official details) but the fact is different of acid containing about $65 \mathrm{ppm}$ uranium. The process is the adjustment stage. The nuclear materials authority is taking over the responsibility for the exploitation of the black sand deposits at the rosetta beach on the mediterranean coast. These deposits contain monazite, zircon and rutile , as well as ilmenite and magnetite. The proposed projects includes wet and dry mills with a capacity for treating $200 \mathrm{~m}^{3}$ / hour (official details) but the fact is different, of wet sand. The area to be evaluated is estimated to contain about six million tonnes of economic heavy minerals at an average grade of $2 \%$ (fact is different). This resource contains about 3000 tonnes of monazite whose $U$ content could be classified as EAR-II. The monazite contains $0.46 \% U$ (fact is over that rate) and $6.05 \%$ Th, As well as $65 \%$ REE at location 6 . The nuclear materials authority concentrated its main explorations activities in the development of three mineralized areas discovered in the Eastern desert and sinai; gabal gattar, El missikat and El erediya, and Abu zeneima as well as Um ara, G. kadabora, Rosette and Sinai. i discuss this activities in details.

3- Radon daughters concentration: Tri met (TM 372-A), portable alpha counter with suitable pump was used. It has a time selector and displays digital reading. The detector is of $\mathrm{ZnS}(\mathrm{Ag})$ scintillator type. The instrument was calibrated with radon daughter source (Po 214) and checked before use by Am 241 alpha standard source. Radon daughter were

\footnotetext{
* Chartered Nuclear Scientist and Professor, Institute of Energy, BRNO University of Technology,
} Czech Rep. Email: ashraf.mohamed@saudieng.org. 
measured using Kuznetz grab sampling method .The maximum permissable radon daughters concentration is 0.3 working level (WL). The total cumulative energy of $1.3 \mathrm{x}$ $10^{5} \mathrm{Mev}$ as alpha particle energy defines the working level as any combination of shortlived decay product of radon gas ( $\mathrm{RaA}, \mathrm{RaB}, \mathrm{RaC}$ and $\mathrm{RaD})$ in one litre of air that will result in the ultimate emission. The working level Month (WLM) is an exposure unit, which is expressed as the product of $\mathrm{WL}$ and duration of exposure, normalised to one month which is defined as 170 hours, i.e. $1 \mathrm{WLM}=170 \mathrm{WLH}$.

4- Monitoring of external gamma radiation: A partable radiation measuring instruments as Geiger counter type, Berthold LB-1200 was used. It gises direct reading for dose rate in millirem/hour. It was calibrated using standard Cs 137 gamma source. It is defined that the maximum permissible value for the dose rate is 2 millirem/hours (Mrem/h) or 20 micro sivert/hour $(\square \mathrm{Sv} / \mathrm{h})$.I show the whole operations in this field. 